\title{
Tumor Findings Collection Date Time
}

National Cancer Institute

\section{Source}

National Cancer Institute. Tumor Findings Collection Date Time. NCI Thesaurus. Code C119926.

The date and time of tumor findings data collection. 